\title{
Investigations on the feeding habits of the rocky-shore mite Hyadesia fusca (Acari: Astigmata : Hyadesiidae): diet range, food preference, food quality, and the implications for distribution patterns
}

\author{
Jens Bücking \\ Universität Bremen, Institut für Ökologie und Evolutionsbiologie; Leobener Str. - NW2, \\ D-28359 Bremen, email: jbueck@biologie.uni-bremen.de
}

\begin{abstract}
Within the food web of estuarine and marine rocky shore ecosystems phytophagous mites of terrestrial and marine origin constitute an important part as grazers on algae and as a food source for certain arthropods, especially zoophagous mites. This investigation deals with the feeding biology of Hyadesia fusca taking as an example a population located on an artificial rocky shore of the middle Weser estuary in Northern Germany. The species is characterized by a broad diet range; in feeding experiments diatoms, lichens, detritus as well as blue, red and green algae were accepted. Even analyses of faecal pellets produced by field specimen suggest a non-specific feeding habit. However, the influence of certain diets on mortality, offspring number and rearing success showed that the food quality differs significantly. The most suitable food, the Ulvaceae Blidingia, was clearly preferred in a series of pairwise choice tests. These findings correlate with the vertical zonation of the field population i.e.: higher population densities in the vegetation zone dominated by Blidingia. It can be concluded that in addition to abiotic factors food supply could play an important role for distribution patterns of phytophagous mites.
\end{abstract}

\section{INTRODUCTION}

Rocky shores are inhabited by a variety of microarthropods of marine as well as terrestrial origin. In the green algae belt of the upper intertidal zone and in the lower supralittoral zone covered with lichens mites often dominate the microfauna with regard to species diversity and abundance (Schuster, 1965; Bartsch, 1978; Bartsch, 1982). Species composition, zoogeography, and vertical distribution of this group are well known (e.g. Halbert, 1920; Otto, 1936; Schuster, 1979; Schulte, 1977; Pugh \& King, 1985 b, c; Ernst et al., 1993), but the functional role of mites in this ecosystem is only poorly understood. Especially the integration of terrestrial microarthropods in the rocky shore food web and the influence of biotic factors such as food supply on distribution patterns needs further investigation.

The mite coenosis of rocky shores comprises a wide spectrum of feeding habits, e.g. zoophagous (e.g. most Gamasina, Rhagidiidae, Erythraeidae, Bdellidae, Halacarinae), phytophagous (e.g. most Oribatida, Nanorchestidae, Hyadesiidae, Rhombognathinae), and saprophagous (some Gamasina, Uropodina, and Oribatida) species (Schuster, 1979; Pugh \& King, 1985a). 
On artificial hardsubstrates of estuaries in northern Germany, especially the surfaceinhabiting algivorous Rhombognathinae and the species Hyadesia fusca (Lohmann) can reach extremely high population densities (Siemer, 1996; Bücking, 1995). At the Baltic Sea Hyadesia fusca often made up over $70 \%$ of the total fauna in brackish-water rock pools with a dense green algae vegetation (Ganning, 1971) and on artificial sea defences (Kronberg, 1983). The Hyadesiidae have a transoceanic distribution and can be found in the intertidal and lower supralittoral of almost every rocky shore. In Europe the distribution of the euryhaline-marine $H$. fusca extends from northern Norway $\left(70^{\circ} \mathrm{N}\right)$ all the way down to the Brittany coast in Northwestern France $\left(48^{\circ} \mathrm{N}\right.$ ) (Schulte, 1977; Schuster, 1988; Fain \& Schuster, 1989). In all known cases they are viviparous; the postnatal development comprises larva, protonymph, tritonymph and the sexual dimorphic adult. Mites of this species can be found (1) epilithic and within the algae cover (Otto, 1936; Kronberg, 1983; Ernst et al., 1993), (2) mesolithic in the outer region or fringe of crevices (Schulte, 1977; Pugh, 1985b), (3) among barnacles (Bénard, 1961; Pugh 1985b) and (4) permanently submersed in the green algae vegetation of rock pools (Halbert, 1920; Ganning, 1970; Östmann \& Rönnberg, 1991). Moreover Ganning (1970) described the inside of the tubular thalli of Enteromorpha intestinalis (L.) Link (Chlorophyta, Ulvaceae) as being a microhabitat of, particularly, the larvae. However, in the Weser estuary $H$. fusca lives only epilithic and within the thin layer of epilithic green algae. During resting phases or periods of desiccation $H$. fusca withdraws into small cavities or congregates at the fringes of crevices (Ernst et al., 1993).

H. fusca is thought to be a specialised inhabitant and feeder of Enteromorpha (Ganning, 1970; Schuster, 1979) but the filamentous green alga Cladophora glomerata Kützing (Ganning, 1971), Cyanophytes (Kronberg, 1983) and microphytes (Bénard, 1961) have also been found in their guts or faecal pellets. $H$. fusca itself is a frequent prey for zoophagous mites like Abrolophus cf. rubipes (Trouessart) and Bdella septemtrionalis Atyeo et Tux. (Witte, 1972; Alberti, 1973) and has been found in the gut of the omniphagous amphipod Platorchestia platensis (Krøyer) (Stueber, pers. comm.), the isopod Ligia oceanica (L.) (v. d. Heydt, pers. comm.) and of the rock pool-inhabiting fish Gasterosteus aculeatus L. (Ganning, 1970).

The vertical distribution of $H$. fusca in the Weser estuary ranges from just below the lower distribution limit of the orange lichen Caloplaca marina (Wedd.) Zahlbr. down to the middle intertidal (Bücking, in press; Ernst, 1996). Nevertheless, the population is concentrated on a narrow band along Mean High Water level (MHW), dominated by green algae of the genus Blidingia. In 1991 a yearly mean abundance of $21 \mathrm{ind} . / \mathrm{cm}^{2}$ and a maximum of 87 ind. $/ \mathrm{cm}^{2}$ was counted in this littoral zone, while only few Hyadesiids have been found in the supralittoral fringe (dominated by Cyanophytes) or in the middle intertidal with its predominant coating with Fucus vesiculosus L. and Enteromorpha intestinalis. Furthermore, it was observed that, when comparing adjacent surfaces that were different in rock type and therefore algae cover (Blidingia on concrete and Enteromorpha on sandstone) but situated on the same tidal level, the population density of $H$. fusca was about ten times higher on the Blidingia-dominated area (Bücking, in press).

The object of this investigation was to answer the question concerning whether the diet range, different feeding preferences or different qualities of the predominant food sources may influence the vertical distribution and population density in certain littoral or vegetational zones. 


\section{MATERIALS AND METHODS}

\section{Sampling and maintenance of the mites}

The sampling of Hyadesiids assigned for laboratory experiments and field experiments was carried out at the location Langlütjen I. This is the ruin of a fortress, located in the mesohaline zone of the middle Weser estuary near Nordenham ( $\mathrm{km} 69.5,53^{\circ} 34^{\prime} \mathrm{N}$. $8^{\circ} 31^{\prime}$ E., salinity 9-19 PSU), extending as a peninsula into the Wadden Sea (Nationalpark Wattenmeer). The mean tidal rise is about $3.6 \mathrm{~m}$; the bank reinforcement ranges from ca. mean sea level up to $2 \mathrm{~m}$ above the mean high water line with a slope of about $40^{\circ}$. The surface consists of weathered sandstone blocks which are stabilised by cast concrete. The vegetation shows a distinct zonation with Enteromorpha sp. and Fucus vesiculosus dominating in the middle intertidal zone, Enteromorpha sp. and Blidingia sp. in the upper intertidal zone, different Cyanophytes (but no black lichens) in the supralittoral fringe and lichens (Caloplaca spp., Xanthoria spp., Lecanora spp.) in the supralittoral zone (Ernst, 1995; Haase, 1995).

The Hyadesiids, obtained from Blidingia samples scraped off the rock surface, were separated into the ontogenetical instars, respectively sexes, and kept in cubic transparent polystyrol chambers $(25 \times 25 \mathrm{~mm}$ surface, $20 \mathrm{~mm}$ high) with lids. The bottom of the vessels was covered with plaster, enriched with a small amount of charcoal. The plaster was moistened with diluted artificial seawater (15 PSU, WIMEX ${ }^{\circledast}$ ) and the vessels stored in a light thermostat at $20 \pm 1^{\circ} \mathrm{C}$ with a $12 \mathrm{~h} / 12 \mathrm{~h}$ light-dark cycle. Saturated air humidity was maintained by adding fresh water whenever necessary.

The algae and lichens assigned as food were sampled at different locations along the meso- and polyhaline zone of the Weser estuary, thoroughly cleaned in diluted seawater with the aid of a dissecting microscope and then distributed in a homogenous thin layer onto the plaster bottom. Surplus and even distribution of the food obviated the need for searching behaviour. The experiments were started by placing the mites into the feeding vessels.

\section{Recording of the diet range in the laboratory and in the field}

After a period of at least 5 hours without food (complete defecation of food ingested before), adults (all tests) and also larvae, protonymphs, and tritonymphs (most tests) were transfered to prepared feeding vessels (one mite per vessel) and checked daily for at least one week. Feeding was attested, if new faecal pellets, clearly distinguishable from food fragments by their peritrophic membrane, were produced.

To examine the diet range in the field, adults from different littoral, or vegetation, zones were collected individually, rinsed in clean sea water, cleaned thoroughly under a field dissecting microscope and then transferred into small glass tubes filled with diluted artificial seawater. Their faecal pellets were analysed for food residues which were compared to preparations of detritus and plant samples collected at exactly the same places. For these analyses squeeze preparations were examined either in vivo or after staining with Toluidin Blue $(1 \%)$ or iodin-iodin-potassium (positive reaction with starch of pyrenoids) with the aid of a DIC microscope (stainings v. Gerlach, 1984). An epifluorescence microscope was used to check the food residues for primary fluorescence and as a test for Cyanophytes (phycocyan-mediated primary fluorescence with green light; see Kronberg, 
1983). The identification of food components in faecal pellets produced by field specimens was facilitated by comparing them to faecal pellets of laboratory specimen fed with certain known diets.

\section{Experiments on food preference}

Different plant species were offered to Hyadesia fusca in several tests with two food types each. The plaster bottom of the feeding vessels, similar to that described above but slightly smaller ( $18 \times 18 \mathrm{~mm}$ surface, $15 \mathrm{~mm}$ high), was provided with food $A$ and with food $B$, each kind covering a third of the total area (Fig. 1). The mites were placed along the midline between food $A$ and $B$ and their actual distribution was checked after 24 hours. A statistically significant difference in the number of test animals on the two food areas was interpreted as a preference for the food type concerned. By keeping the rela-

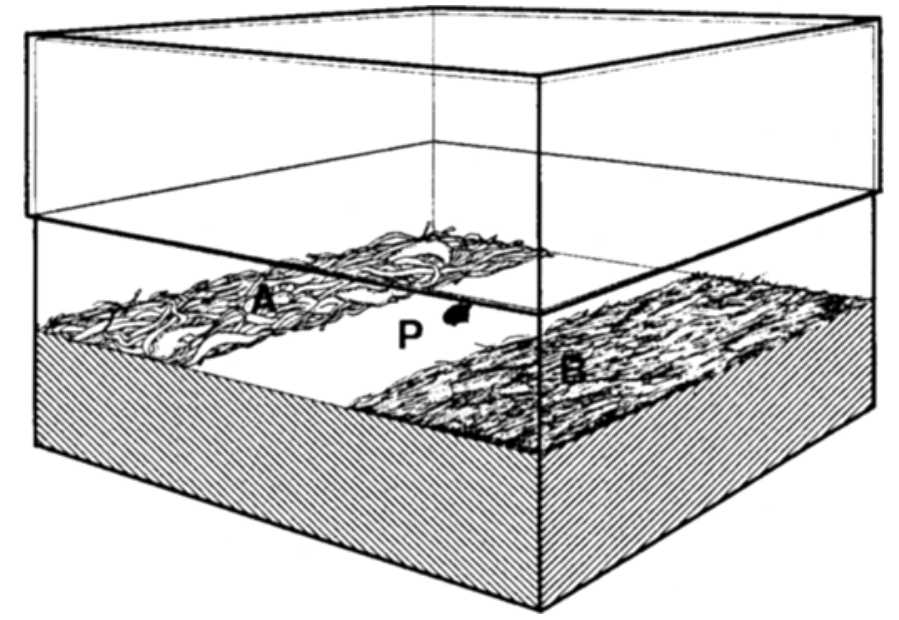

Fig. 1. Design of the polystyrol vessels used for the experiments on choice of food $(18 \times 18 \times 15 \mathrm{~mm})$. $\mathrm{A}=\operatorname{Food} \mathrm{A}_{i} \mathrm{~B}=$ Food $\mathrm{B} ; \mathrm{P}=$ Plaster of Paris-Charcoal Mixture

tive air humidity at $100 \%$ and by diffuse illumination, humidity gradients and phototaxis were be ruled out as factors influencing the choice behaviour.

The green algae Blidingia minima (Näg. ex Kütz.) Kylin, Enteromorpha intestinalis and Rhizoclonium riparium (Roth) Harv, as well as the lichen Caloplaca marina were compared, using 12 vessels per comparison each with 10 females. To take into account possible differences in the behaviour of instars and sexes, the distribution of females, males and tritonymphs (each $3 \times 10$ ) after a period of 24 hours was compared in an additional pairwise-choice test with Blidingia and Enteromorpha. In order to study individual behaviour, 17 females were each placed in the centre of a vessel provided with Blidingia minima and Enteromorpha intestinalis and observed continuously for 6 hours. The intensity of feeding was checked by counting the faecal pellets per area after 24 hours. 
The effect of diets on mortality, reproductivity, and development

After sampling and storage for one day in the light thermostat without food, 20 females per diet were each placed in a feeding vessel of their own and checked every second or third day. New-born larvae were counted and removed at every control. Some of these larvae were transfered to feeding vessels with the same diet, and their further development was checked daily or every second day. Non-feeding mites and specimen that died owing to extemal factors (e.g. injury) were ignored for data evaluation.

The period of time between the first and last appearance of new-born larvae was defined as duration of reproduction. The mean birth rate for each female is the quotient of the duration of reproduction and the total number of larvae. In the case of females without offspring between start of investigation and death but who posthumously were found with fully developed embryos within their idiosoma (checked by squeezed preparations), the duration of reproduction and the birth rate was rated as zero.

Forage used for the food quality experiments was collected at different locations in the Weser estuary; the lichen Caloplaca marina from the supralittoral zone and the Chlorophytes Prasiola stipitata Suhr in Jessen from the supralittoral fringe, Blidingia and Rhizoclonium riparium from the upper intertidal and Enteromorpha intestinalis from the middle intertidal.

\section{Statistics}

The statistical treatment of the preference experiment is based on the assumption that without any attraction or repulsion of the two food sources the individuals would be distributed homogeneously on the vessels bottom. For simplification, the few specimen found on the vessels walls were added to those on the uncovered plaster area. A chi-square test was carried out to compare the expected and observed frequencies of specimens cumulated for the three areas of the 12 vessels $\left(\mathrm{H}_{0}: \mathrm{E}_{\mathrm{Food} \mathrm{A}}=\mathrm{E}_{\mathrm{Food} \mathrm{B}}=\mathrm{E}_{\text {Plaster/Walls }}=\right.$ $1 / 3, n=120, d f=2, p<0.01$ ). If this test indicated an inhomogeneous distribution, the "more attractive" food area was compared to the remaining area by a chi-square test for $\mathrm{H}_{0}: \mathrm{E}_{\text {Food A }}=1 / 3, \mathrm{E}_{\text {Food } \mathrm{B}+\text { Plaster } / \text { Walls }}=2 / 3(\mathrm{n}=120, \mathrm{df}=1, \mathrm{p}<0.01)$.

The low sample size for the experiments on food quality implied that no reliable test on normal distribution could be carried out. Therefore, the effect of different diets on mortality, reproduction and development was compared using the two-tailed non parametric U-test after Mann \& Whitney $(p<0.05)$. A possible connection between long reproduction time and low birth rate was tested using the Spearman coefficient of rank correlation. ( $\mathrm{p}$ for $[\mathrm{H} 1: \mathrm{R} \neq 0]<0.05$ ).

All statistical tests mentioned above were calculated according to Köhler et al. (1992).

\section{RESULTS}

\section{Diet range}

Table 1 shows the results of the feeding tests with marine and habitat-extraneous food.

Except for Fucus vesiculosus and Ulva lactuca L. (which have comparatively firm tissue), all other marine macroalgae, microalgae, lichens and detritus were accepted as 
Table 1. Laboratory results of supply experiments with various kinds of food (+ accepted, - not accepted, "only adults tested)

\begin{tabular}{|c|c|c|}
\hline Food source & Sample site & Result \\
\hline \multicolumn{3}{|l|}{ Marine plants (Weser estuary) } \\
\hline Xanthoria parietina (L.) (Lichenophyta) & upper supralittoral & + \\
\hline Caloplaca marina (Lichenophyta) & lower supralittoral & + \\
\hline Different coccal and filamentous Cyanophyta & supralittoral fringe & + \\
\hline Prasiola stipitata (Chlorophyta) & supralittoral fringe & + \\
\hline Blidingia minima (Chlorophyta) & upper intertidal & + \\
\hline Rhizoclonium riparium (Chlorophyta) & upper intertidal & + \\
\hline Detritus floccules (inclusive different microphytes) & middie intertidal & $++^{*}$ \\
\hline Enteromorpha intestinalis (Chlorophyta) & middle intertidal & + \\
\hline Rhodochorton sp. (Rhodophyta) with epiphytic diatoms & lower intertidal & + \\
\hline Epiphytic microalgae on Fucus vesiculosus & lower intertidal & $++^{*}$ \\
\hline Young Fucus vesiculosus (without epiphytes) (Phaeophyta) & lower intertidal & ${ }_{-}^{*}$ \\
\hline Ulva lactuca (Chlorophyta) & lower intertidal & $-{ }^{*}$ \\
\hline \multicolumn{3}{|l|}{ Fresh and decayed carrion (Weser estuary) } \\
\hline Anurida maritima (Guerin) (Collembola) & upper intertidal & $\stackrel{\cdot}{-}$ \\
\hline Ligia oceanica (L.) (Isopoda) & upper intertidal & $-{ }^{*}$ \\
\hline \multicolumn{3}{|l|}{ Habitat-extraneous food } \\
\hline Ulothrix sp. (Chlorophyta) & limnic sublittoral & + \\
\hline Pleurococcus sp. (Chlorophyta) & tree bark & $-\cdot$ \\
\hline Myriophyllum spicatum (L.) (Rosidae) & pond & $-^{*}$ \\
\hline Elodea canadensis (Michx.) (Alismatidae) & pond & $-^{*}$ \\
\hline Sphagnum sp. (Bryophyta) & peat-bog & - $^{\cdot}$ \\
\hline Birch leaves in various degrees of decomposition & edge of a forest & _. \\
\hline Laccaria laccata (Skop. ex. Fr.) Berk ex Br. Mycelium (Fungi) & laboratory culture & $-^{*}$ \\
\hline
\end{tabular}

food. Fresh and decaying carcasses were never accepted, even when the specimen were exposed to longer periods of starvation. Habitat-extraneous food was not accepted, with one exception i.e. a limnic species of epilithic growing Ulothrix sp., a sublittoral filamentous green alga sampled at a bank reinforcement of the Ijsselmeer (0.5 PSU, Netherlands). Many species of this genus are also present on marine and estuarine hardsubstrates.

The results of these laboratory tests were compared to results of analyses of faecal pellets obtained from mites sampled in the field (Table 2).

The food is obviously only partially digested by Hyadesia. With Enteromorpha as a food component, cell wall fragments, parts of chloroplasts, pyrenoids and, in few cases, also intact cells occurred in the faecal pellets. With Blidingia as food, additionally fragments of thalli consisting of up to 10 cells were found. Fine filamentous green algae were merely fragmented into smaller parts as a result of food processing (Fig. 2). Diatoms were detected either as intact individuals, empty shells or fragments of shells. Most of the Cyanophytes were found intact either as clusters of coccal species (e.g. Chroococcus) or as fragments of filamentous species (e.g. Oscillatoria). Many of the algae fragments found in the faecal pellets showed primary fluorescence comparable to that of living 
Table 2. Food components in faecal pellets of Hyadesia fusca adults, sampled in various littoral and vegetational zones

\begin{tabular}{|ll|}
\hline Sample site & $\begin{array}{l}\text { Food components (in order of decreasing } \\
\text { estimated proportion) }\end{array}$ \\
\hline $\begin{array}{l}\text { Littoral fringe (sandstone), dominated by } \\
\text { tetrasporal Cyanophytes (Chroococcus sp.) }\end{array}$ & $\begin{array}{l}\text { Cyanophytes, Blidingia sp., epiphytic diatoms, } \\
\text { coccal Chlorophytes, fungal hyphae }\end{array}$ \\
$\begin{array}{l}\text { Upper intertidal (concrete), dominated by } \\
\text { Blidingia sp. }\end{array}$ & $\begin{array}{l}\text { Blidingia sp., diatoms, different Cyanophytes, } \\
\text { filamentous Chlorophytes }\end{array}$ \\
$\begin{array}{l}\text { Upper intertidal (sandstone), in the upper } \\
\text { part dominated by Blidingia sp., in the lower } \\
\text { part dominated by Enteromorpha sp. }\end{array}$ & $\begin{array}{l}\text { Blidingia sp., Cyanophytes, Enteromorpha sp., } \\
\text { benthic diatoms, filamentous Chlorophytes, } \\
\text { sediment particles }\end{array}$ \\
$\begin{array}{l}\text { Middle intertidal (hardened sediment layer) } \\
\text { with diatoms and few filamentous }\end{array}$ & diatoms \\
Rhodophyta & \\
\hline
\end{tabular}

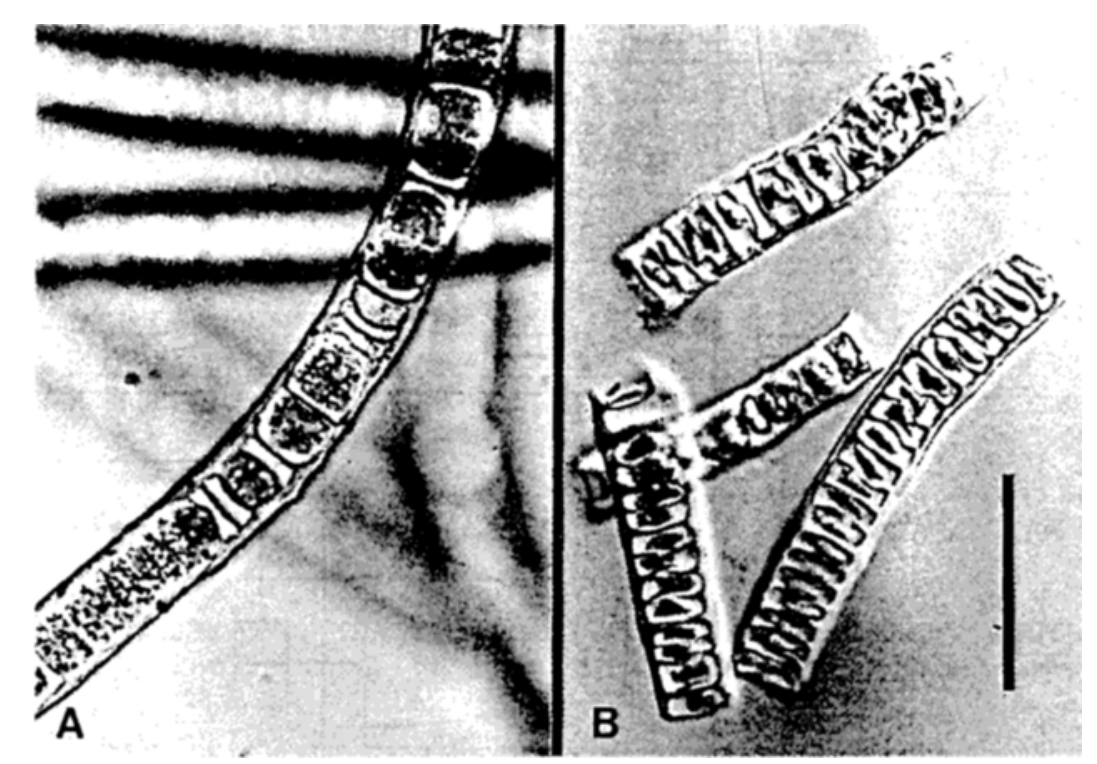

Fig, 2. A: Filamentous green alga, sampled at the ferry landing place Dedesdorf, Weser estuary; $B$ : content of faecal pellets of an adult fed with this alga. Bar $=30 \mu \mathrm{m}$ 
algae. Faecal pellets left on moist plaster for some days often gave rise to a growth of green algae germlings, which penetrated the peritrophic membrane.

The analysis of samples taken from the natural habitat confirmed largely the results of the feeding tests. Quantity and frequency of the food components from adults of a distinct vegetation zone represented to some extent the respective food supply at the sample place. As an exception, the faecal pellets produced by mites sampled in the supralittoral fringe regularly contained Blidingia cells, though this alga occurred in this zone only as patches of few germlings. The occasional appearance of benthic diatoms and of sediment particles within the faecal pellets indicate that detritus is, albeit to a small extent, a part of the food ingested.

\section{Food preference}

Figure 3 shows the results of the pairwise-choice test with 10 females per vessel. A significant inhomogenous distribution of the test population was recorded in all tests, except in the trial with Rhizoclonium - Caloplaca. The mites showed a strong preference for Blidingia $\left(\chi^{2}>100\right)$. Furthermore, they were more abundant on Rhizoclonium if compared with Enteromorpha + Plaster/Walls $\left(\chi^{2}=11\right)$, and on Enteromorpha if compared with

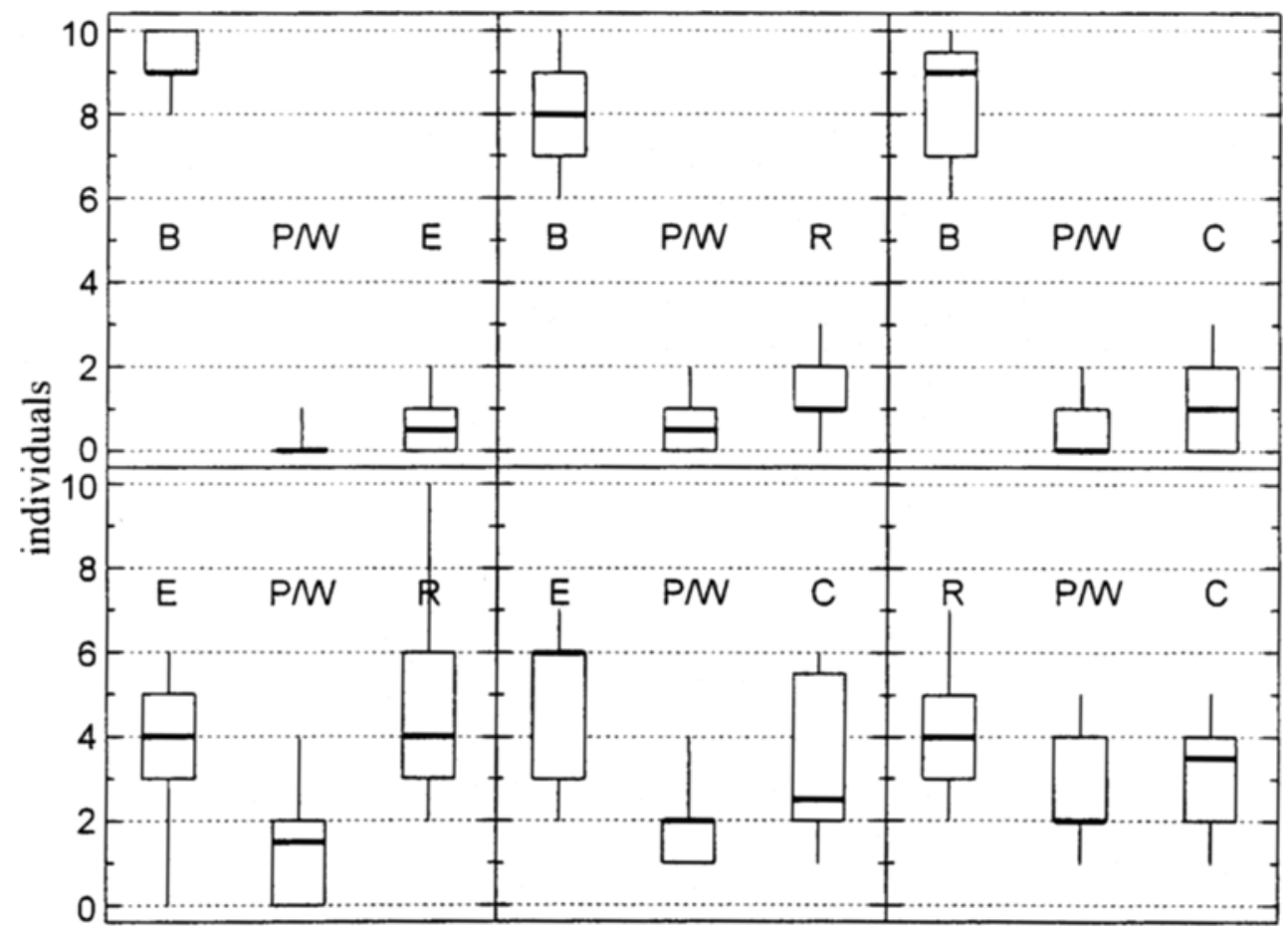

Fig. 3. Distribution of the test populations in the vessels in which a choice of food was offered. Box \& Whisker Plot with median (bold line), interquartil range (boxes) and range (whiskers); $\mathrm{n}=12$ with 10 individuals each. $\mathrm{B}=$ Blidingia, $\mathrm{E}=$ Enteromorpha, $\mathrm{R}=$ Rhizoclonium, $\mathrm{C}=$ Caloplaca, $\mathrm{P} / \mathrm{W}=$ Plaster and Walls 
Caloplaca + Plaster/Walls $\left(\chi^{2}=14\right)$. These two "preferences" have to be treated with caution regarding the relatively high variability (Fig. 3). With the exception of some trials with Blidingia supply, faecal pellets were found on both food areas of the vessels.

The distribution of the 30 females, males, and tritonymphs was 24,27 and 26 individuals, respectively, on the Blidingia area (compared with Enteromorpha), thus significant differences in the choice behaviour of sexes or instars did not occur.

During $6 \mathrm{~h}$ of continuous observation, only 4 of 17 individually kept females moved to the Enteromorpha area, and only one of these fed on this alga, but within the first hour all migrated over to the Blidingia area. The mean number of faecal pellets per female and day was 18 (max. 36) on the Blidingia area, and 1 (max. 13) on the Enteromorpha area.

\section{Food quality}

Differences in the nutritional quality of certain algae or lichens were tested regarding their dietary influence on survival time and reproduction of females and on the postnatal development of larvae (Table 3). It must be noted that the females originated from field samples, therefore individual age, number of previous births and the actual stock of

Table 3. Comparison of various food sources with regard to their effect on survival, larval births and development time. Arithmetic mean, standard deviation, range (in brackets) and sample size stated. Different characters in a column indicate significant differences (U-test after Mann \& Whitney, $\mathrm{p}<0.05)$

\begin{tabular}{|c|c|c|c|c|c|}
\hline $\begin{array}{l}\text { Food } \\
\text { source }\end{array}$ & $\begin{array}{l}\text { Survival } \\
\text { time (d) }\end{array}$ & $\begin{array}{l}\text { Duration of } \\
\text { reproduction } \\
\text { (d) }\end{array}$ & $\begin{array}{l}\text { Total number } \\
\text { of larvae per } \\
\text { female }\end{array}$ & $\begin{array}{l}\text { Individual birth } \\
\text { rate (larvae per } \\
\text { female } \mathrm{x} \mathrm{d}^{-\mathrm{i}} \text { ) }\end{array}$ & $\begin{array}{l}\text { Development } \\
\text { time (birth to } \\
\text { adult) (d) }\end{array}$ \\
\hline Blidingia & $\begin{array}{c}79 \pm 39 a \\
(21-136) \\
16\end{array}$ & $\begin{array}{c}45 \pm 17 a \\
(7-69) \\
15\end{array}$ & $\begin{array}{c}26 \pm 10 \mathrm{a} \\
(5-38) \\
15\end{array}$ & $\begin{array}{c}0.60 \pm 0.14 \mathrm{a} \\
(0.38-0.90) \\
15\end{array}$ & $\begin{array}{c}44 \pm 7 a \\
(33-58) \\
9\end{array}$ \\
\hline Enterom. & $\begin{array}{c}28 \pm 20 b \\
(6-101) \\
19\end{array}$ & $\begin{array}{c}10 \pm 6 b \\
(3-26) \\
17\end{array}$ & $\begin{array}{c}7 \pm 3 b \\
(3-14) \\
17\end{array}$ & $\begin{array}{c}0.75 \pm 0.38 a \\
(0.29-1.75) \\
17\end{array}$ & $\begin{array}{c}50 \pm 10 a, b \\
(39-60) \\
3\end{array}$ \\
\hline Rhizocl. & $\begin{array}{c}40 \pm 25 b \\
(10-91) \\
19\end{array}$ & $\begin{array}{c}17 \pm 15 b \\
(4-46) \\
17\end{array}$ & $\begin{array}{c}9 \pm 7 b \\
(3-30) \\
17\end{array}$ & $\begin{array}{c}0.72 \pm 0.35 a \\
(0.17-1.50) \\
17\end{array}$ & $\begin{array}{c}47 \pm 8 a, b \\
(36-56) \\
4\end{array}$ \\
\hline Prasiola & $\begin{array}{c}28 \pm 22 b, c \\
(10-87) \\
18\end{array}$ & $\begin{array}{c}15 \pm 23 \mathrm{~b}, \mathrm{c} \\
(0-67) \\
18\end{array}$ & $\begin{array}{c}7 \pm 8 b, c \\
(0-25) \\
18\end{array}$ & $\begin{array}{c}0.55 \pm 0.43 \mathrm{a}, \mathrm{b} \\
(0.00-1.50) \\
18\end{array}$ & $\begin{array}{c}101 \pm 37 b \\
(52-140) \\
4\end{array}$ \\
\hline Caloplaca & $\begin{array}{c}34 \pm 22 \mathrm{~b}, \mathrm{c} \\
(5-70) \\
16\end{array}$ & $\begin{array}{c}19 \pm 16 b \\
(1-47) \\
14\end{array}$ & $\begin{array}{c}6 \pm 4 b, c \\
(1-14) \\
14\end{array}$ & $\begin{array}{c}0.43 \pm 0.31 \mathrm{~b} \\
(0.10-1.25) \\
14\end{array}$ & $\begin{array}{c}73 \pm 29 \mathrm{a}, \mathrm{b} \\
(53-94) \\
2\end{array}$ \\
\hline Unfed & $\begin{array}{c}17 \pm 6 c \\
(10-37) \\
20\end{array}$ & $\begin{array}{c}4 \pm 3 c \\
(0-9) \\
17\end{array}$ & $\begin{array}{c}4 \pm 3 c \\
(0-12) \\
17\end{array}$ & $\begin{array}{c}0.80 \pm 0.68 \mathrm{a}, \mathrm{b} \\
(0.00-2.25) \\
17\end{array}$ & - \\
\hline
\end{tabular}


sperm within the receptaculum seminis were unknown. The values given below can be used to show relative differences in the effect of various diets, but do not fully represent the species-specific mean of lifetime, reproduction period or fecundity.

In the following text, differences of mean values as shown in Table 3 are pointed out in context with the development in time.

\section{Mortality}

Compared to all other diets, a Blidingia diet ensured significantly longer survival.

No significant differences were ascertained in the other feeding tests. Compared to unfed individuals, only those fed on algae had a significantly higher mean survival time. Figure 4 shows the relative portion of survivors in the period after the observation began. Every dot in the figure represents a day on which the death of one or more mite(s) was ascertained.

Corresponding data on Blidingia and Rhizoclonium as a food source exist also for adults reared in the laboratory from larvae. The mean survival time was 100 days $(\mathrm{SD}=51$, range $29-235, \mathrm{n}=15$ ) on Blidingia and 54 days $(\mathrm{SD}=48$, range $13-129, \mathrm{n}=6$ ) if fed with Rhizoclonium. Even though these values tend to be higher than those for field adults of unknown age (differences not significant), they show the same relation of ca. $2: 1$.

\section{Reproduction}

The duration of reproduction and the number of births of females fed with Blidingia was about twice as high compared to those of females fed with other diets. Both parameters are coupled with the individual survival time of the respective females. The birth rate obtained with the feeding of the various green algae ranged from 0.55 to 0.75 larvae per female/day (no significant differences, see Table 3). The birth rate of females fed with the lichen Caloplaca was significantly lower than that of females fed on other diets except for Prasiola. While the birth rate of the mites kept on Blidingia varied relatively little, the respective data of mites fed with other food had a high range. The unfed females differed from the fed ones in their very short reproduction period with frequent larvae births, which explains the unexpectedly high birth rate.

Looking at the development of the birth rate in the course of the experiment, it could be seen that with Blidingia as food larvae births occurred regularly during the entire reproductive period. With all other diets, except for the short-living females with Enteromorpha supply, at the very latest after three weeks of the diets longer periods of up to 29 days (Rhizoclonium) with no larvae production occurred. Figure 5 shows such interruptions of births comparing Blidingia, Prasiola, and Caloplaca.

A significant negative correlation between reproduction period and birth rate was found for the females fed with Rhizoclonium, Prasiola, and Caloplaca $(\mathrm{R}=-0.72$ to -0.78 , $\mathrm{n}=14-17)$.

\section{Development}

Regarding the time period from birth to adult hatch (Table 3), development was retarded in females on a diet of Prasiola and of Caloplaca. Figure 6 shows the development of individuals for all diets tested (total lifetime of adults is not stated). 


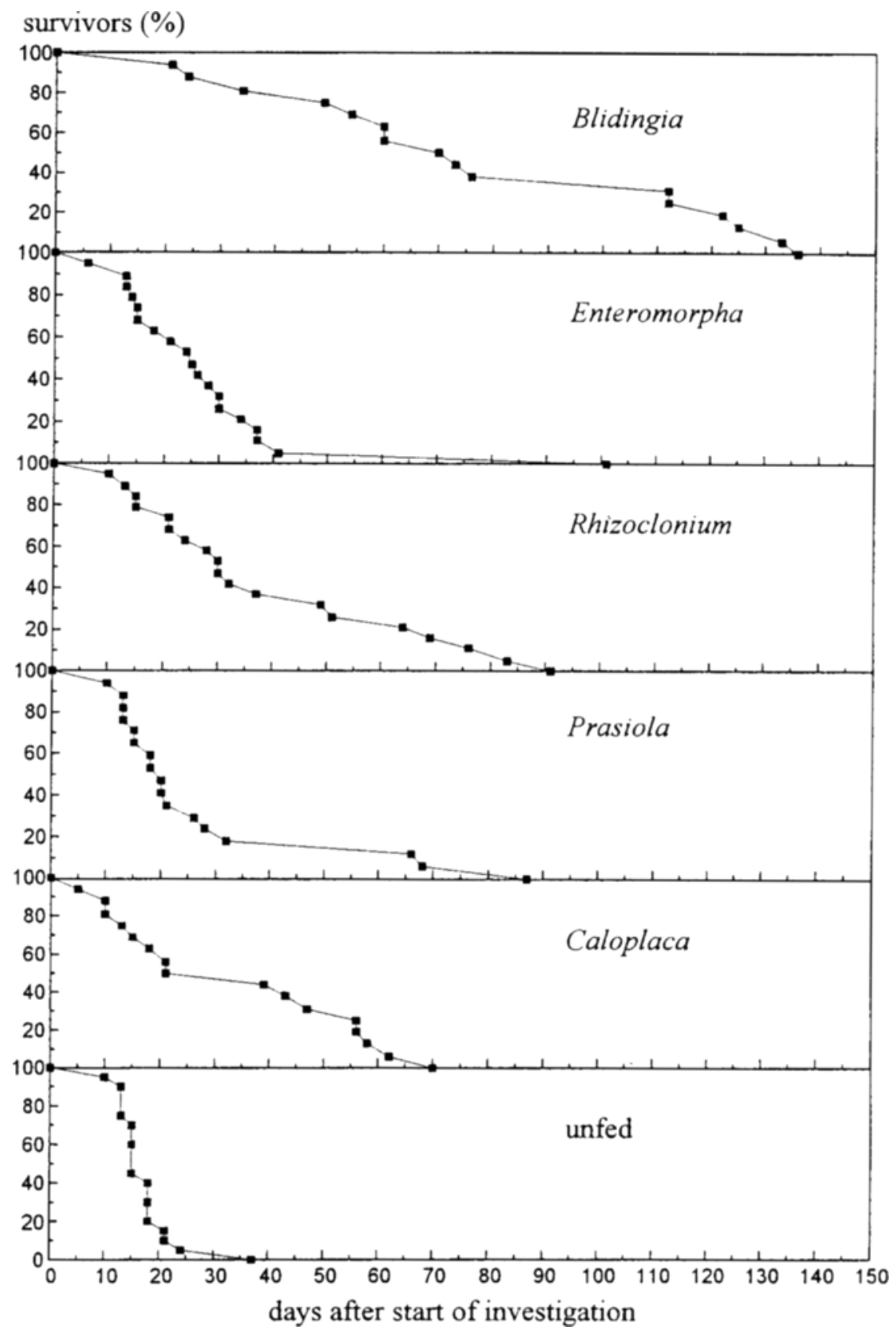

Fig. 4. Survival time of females fed with various diets 

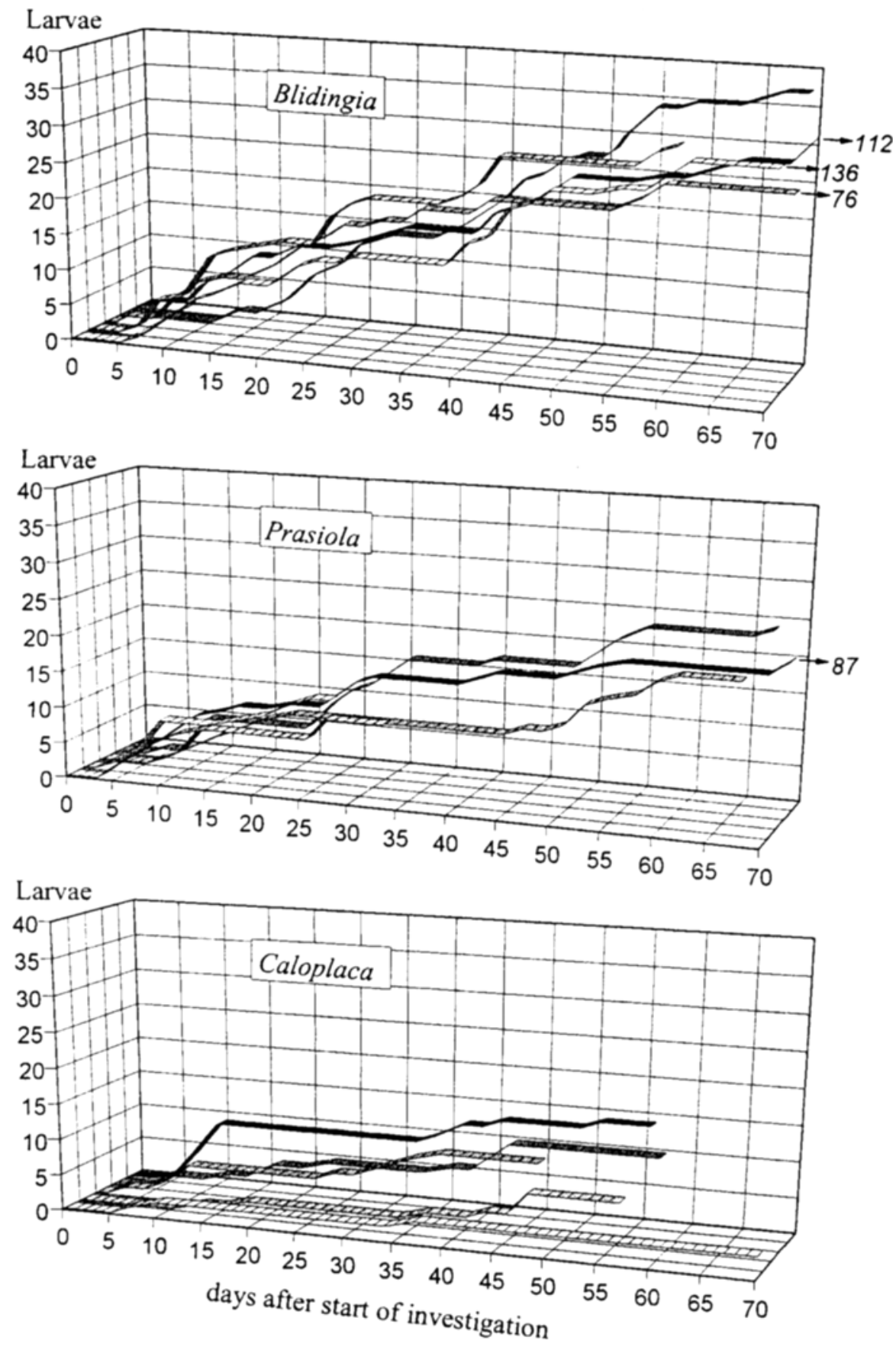

Fig. 5. Larvae births (cumulative) after start of observation of the respective five females with the longest duration of reproduction. The arrows point out the overall survival time of the female (without further larvae births) 


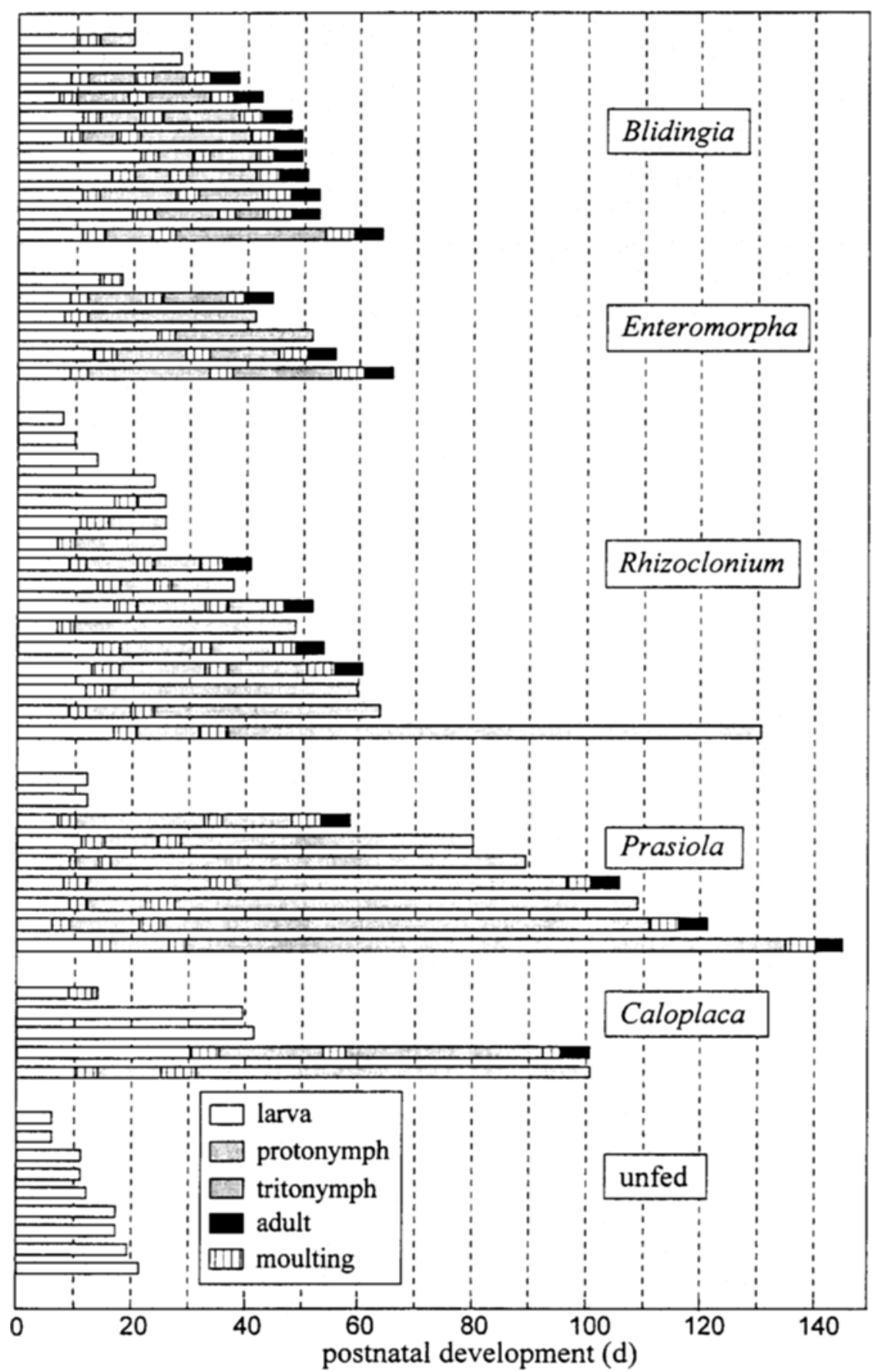

Fig. 6. Postnatal development from larva birth to adult hatch, comparing various diets at $20^{\circ} \mathrm{C}$ with a 12 hour light/dark cycle (duration of the adult instar not given) 
The various diets differed in their effect on the rearing success. About $80 \%$ of the offspring reared on Blidingia finally hatched to adults; with other food supplies it was only 20 to $50 \%$. Unfed larvae showed no further development. The duration of development with different diets showed a high variability, both within groups and between groups. While one new-born larva reached adulthood in only 33 days (Blidingia), another took 140 days (Prasiola). The above mentioned retardation of development can obviously occur in all ontogenetical instars; conspicuous are the prolongation of the protonymphal instar if fed with Enteromorpha and the prolongation of the tritonymphal instar if fed with Prasiola. In some cases, development stopped though death occurred much later (up to three months). The frequency of such development retardations was low if reared on Blidingia and high with other food supply.

\section{DISCUSSION}

\section{Feeding habits and food quality}

This investigation shows that Hyadesia fusca has a substantially broader diet range than was formerly suspected. In Table 4 an overview of the updated results of gut content or faecal pellet analysis carried out in species of the family Hyadesiidae is given.

All Hyadesiids appear to be microphytophagous (in the sense of Schuster, 1956), but some also accept detritus as food. However, it can be assumed that the actual spectrum of food of the species listed in Table 4 is much broader.

The diet range of the observed population is probably more or less dependent on the accessibility of suitable food at the respective sample site. However, food ingestion does not automatically imply food utilisation. Judging by the observations that (1) H. fusca has a clear preference for a distinct green alga with high nutritional value and (2) green algae constitute a food component of nearly all investigated Hyadesiids, one may assume that this taxon is mainly algivorous. Nevertheless, the role played by the epiphytic microflora of macroalgae in the nutrition of Hyadesiids is still unknown. However, the bacteria-rich detritus constitutes only a small part of the food of $H$. fusca. A comparison of the nutritional quality of food samples from the field used in this investigation with that of axenic algae cultures could, perhaps, clarify the issue.

Higher plants and macroalgae with relatively firm tissues e.g. Fucus and Ulva were not accepted in the feeding tests. Tissue structure and therefore the ease with which the mites can manipulate and ingest their food is probably an important factor that influences the diet range of $H$. fusca. This assumption is further supported by the finding that Enteromorpha intestinalis, which is closely related to Blidingia minima but has greater cell lumina $(12 \times 12-20 \times 15 \mu \mathrm{m}$ versus $5-7 \mu \mathrm{m}$ diameter) and thicker cell walls (Bliding, 1963), is a low-quality food. Furthermore, in the course of the supply experiments the number of faecal pellets produced offering Enteromorpha as food was very low compared to that of Blidingia-fed test animals. Schulte (1976) assumed for certain algophagous mites of the genus Ameronothrus that the instar specific diet range correlates with the size of the chelicerae and depends mainly on tissue firmness and structure, but not on chemical composition of the algae. Larvae and protonymphs accepted only coccal algae and fungi, whereas deutonymphs, tritonymphs and adults fed also on macroalgae or lichens. Siemer (in press) found that the tiny larvae of the halacarid mite Metarhom- 
Table 4. Gut content and/or faecal pellet analyses of certain species of Hyadesiidae

\begin{tabular}{|c|c|c|c|}
\hline Species & Reference & Sample site & Gut/faecal pellet contents \\
\hline \multirow[t]{4}{*}{$\begin{array}{l}\text { Hyadesia fusca } \\
\text { (Lohmann, 1894) }\end{array}$} & Ganning, 1970 & $\begin{array}{l}\text { supralittoral rock pools, } \\
\text { North sea and Baitic sea }\end{array}$ & $\begin{array}{l}\text { Enteromorpha intestinalis, } \\
\text { possibly epiphytic bacteria }\end{array}$ \\
\hline & Ganning, 1971 & dito & Cladophora glomerata, \\
\hline & Bénard, $1961^{\circ}$ & $\begin{array}{l}\text { barnacles, Northwest- } \\
\text { France (Cotentin, } \\
\text { Bretagne) }\end{array}$ & $\begin{array}{l}\text { mucous layer on barnacles } \\
\text { with unicellular algae, } \\
\text { bacteria and diatoms }\end{array}$ \\
\hline & $\begin{array}{l}\text { this } \\
\text { investigation }\end{array}$ & $\begin{array}{l}\text { estuarine intertidal } \\
\text { and lower supralittoral } \\
\text { of embankments } \\
\text { (Northern Germany) }\end{array}$ & $\begin{array}{l}\text { different macroalgae } \\
\text { (Ulvales, Prasiolales, } \\
\text { Cladophorales), } \\
\text { microalgae (Cyanophytes, } \\
\text { diatoms, unicellular green } \\
\text { algae), detritus (incl. its } \\
\text { microflora). In the labora- } \\
\text { tory also Rhodophyta } \\
\text { and lichens }\end{array}$ \\
\hline $\begin{array}{l}\text { Hyadesia tumida } \\
\text { Bénard, } 1961\end{array}$ & Bénard, 1961 & $\begin{array}{l}\text { barnacles, Northwest- } \\
\text { France (Cotentin, } \\
\text { Bretagne) }\end{array}$ & $\begin{array}{l}\text { mucous layer on barnacles } \\
\text { with uniceliular green } \\
\text { algae, bacteria and diatoms }\end{array}$ \\
\hline $\begin{array}{l}\text { Hyadesia sellai } \\
\text { Viets, } 1937\end{array}$ & Schuster, 1979 & $\begin{array}{l}\text { intertidal rocks and } \\
\text { inside the cavity system } \\
\text { of the Lithophyllum. } \\
\text { trottoir, Italian adria }\end{array}$ & $\begin{array}{l}\text { predominantly green } \\
\text { algae, few Cyanophytes }\end{array}$ \\
\hline $\begin{array}{l}\text { Amhyadesia } \\
\text { costaricensis Fain } \\
\text { \& Schuster, } 1984\end{array}$ & $\begin{array}{l}\text { Fain \& Schuster, } \\
1984 \text { b }\end{array}$ & $\begin{array}{l}\text { rocks of the upper } \\
\text { intertidal (Costa Rica) }\end{array}$ & $\begin{array}{l}\text { green algae (among } \\
\text { others) }\end{array}$ \\
\hline $\begin{array}{l}\text { Amhyadesia } \\
\text { brasiliensis Fain \& } \\
\text { Schuster, } 1984\end{array}$ & $\begin{array}{l}\text { Fain \& Schuster, } \\
1984 \mathrm{~b}\end{array}$ & $\begin{array}{l}\text { rocks of the upper } \\
\text { intertidal with sessile } \\
\text { fauna or epilithic algae } \\
\text { turf (Brasil) }\end{array}$ & $\begin{array}{l}\text { leftover of green algae } \\
\text { thalli, Cyanophyta, } \\
\text { seldom diatoms }\end{array}$ \\
\hline $\begin{array}{l}\text { Amhyadesia } \\
\text { heterophallus Fain } \\
\text { \& Schuster, } 1984\end{array}$ & $\begin{array}{l}\text { Fain \& Schuster, } \\
1984 \mathrm{a}\end{array}$ & $\begin{array}{l}\text { intertidal rocks, partly } \\
\text { with calcareous algae } \\
\text { (Maledives and } \\
\text { Philippines) }\end{array}$ & $\begin{array}{l}\text { presumably, green algae } \\
\text { (green gut content) }\end{array}$ \\
\hline $\begin{array}{l}\text { Hyadesia } \\
\text { verrucosa Fain \& } \\
\text { Schuster, } 1985\end{array}$ & $\begin{array}{l}\text { Fain \& Schuster, } \\
1985\end{array}$ & $\begin{array}{l}\text { in depressions and } \\
\text { crevices of intertidal } \\
\text { rocks, covered with } \\
\text { green algae (Istria, } \\
\text { former Yugoslavia) }\end{array}$ & $\begin{array}{l}\text { presumably, green algae } \\
\text { (green gut content and } \\
\text { green faecal pellets) }\end{array}$ \\
\hline $\begin{array}{l}\text { Hyadesia } \\
\text { kerguelensis } \\
\text { Lohmann, } 1907\end{array}$ & Travé, 1988 & $\begin{array}{l}\text { in the Verrucaria-belt } \\
\text { of the intertidal } \\
\text { (Kerguelen islands) }\end{array}$ & $\begin{array}{l}\text { Verrucaria sp. (lichens, } \\
\text { only the phycobiont) }\end{array}$ \\
\hline $\begin{array}{l}\text { Hyadesia zelandica } \\
\text { Luxton, } 1989\end{array}$ & Luxton, 1989 & $\begin{array}{l}\text { on rocks of the upper } \\
\text { intertidal among } \\
\text { barnacles, in fissures } \\
\text { of encrustated oysters, } \\
\text { on lichens and in other } \\
\text { places (New Zealand) }\end{array}$ & detritus \\
\hline \multicolumn{4}{|c|}{$\begin{array}{l}\text { - Bénard (1961) described this for } H \text {. furcillipes Bénard, 1961, which is according to Fain (1981) } \\
\text { a synonym of } H \text {. fusca (Lohmann, 1894). }\end{array}$} \\
\hline
\end{tabular}


bognathus armatus (Lohmann) cannot proceed with their postembryonic development if kept on Enteromorpha as opposed to those kept on Blidingia. However, field adults had the same longevity on both algae.

The spectrum of accepted food at different localities may be influenced by the fact that the shape of thalli and thickness of cell wall of certain algae species may vary greatly under different abiotic conditions (e.g. Bliding, 1963). Young et al. (1987) have shown that Enteromorpha intestinalis from estuarine locations has thinner cell walls compared to the same alga from fully marine habitats. On the other hand, the low nutritional quality of certain filamentous or thin monostromatic algae, e.g. Rhizoclonium and Prasiola for $H$. fusca (this observation) or Prasiola for M. armatus (Siemer, in press), is evidence that a firm tissue cannot be the only reason for a low suitability.

Other possible factors influencing the suitability or acceptance of food could be (1) the energy and water content; (2) the carbohydrate and nutrient composition (e.g. starch, lipid, polyol, amino acids and vitamin content); (3) the relative proportion of indigestible components and (4) possible mechanisms of the algae that protect from being fed on. Levinson et al. (1992) reported the significant influence of various vitamins on lifetime, fecundity, and development in the flour mite Acarus siro L. (Astigmata: Acaridae). Bowman \& Childs (1982) found amylase and chitinase in all of the six investigated Astigmatid mite species, and cellulase in two of them. However, the possible role of endosymbionts and their enzymes in the digestion of cell walls, well known in insects, is not fully understood in the case of mites.

One possible mechanism for algae to protect themselves from grazers is chemical defence (Paul, 1992), e.g. the production of toxic phenols and tannins as described for brown algae (Carefoot, 1977; Roussis et al., 1993; Winter \& Estes, 1992). Many green algae, e.g. Blidingia, Enteromorpha and Ulva, produce a great amount of Dimethylsulfoniumpropionate (DMSP) (Reed, 1983), which is discussed to have protecting features, possibly due to the release of acrylic acid (Glombitzka, 1970; Keller et al., 1989). At least for $H$. fusca with its preference for Blidingia the DMSP seems not to be a deterrent.

The experiments on food preference revealed a searching behaviour favouring Blidingia, but the causality of this behaviour, e.g. different palatability, attractants of the preferred food, deterrents or repellents of the avoided food, mechanical stimuli (size and shape of thalli), remains unclear. However, the preference behaviour of $H$. fusca is obviously correlated to the suitability of the respective food. Contradicting this, Paine \& Vadas (1969) concluded that availability of seaweeds, and not absolute food value, was a more decisive factor for the evolution of preferences of marine herbivores. For example, Carefoot (1973) has shown for the supralittoral isopod Ligia pallasii (Brandt) that feeding preference is not necessarily linked to the energy content of the food. On the other hand, in some cases food that was in short supply or totally absent in the natural habitat of certain marine herbivores was preferred in laboratory tests (Leighton \& Boolootian, 1963; Carefoot, 1970, 1973).

\section{The influence of feeding habits on distribution patterns}

A migration to surfaces covered with Blidingia and a low mortality of juveniles and adults - accompanied by a higher fecundity - would lead to higher population densities. Evidence that preference behaviour and food quality could affect distribution patterns 
and population density is given by the fact that a higher abundance of Hyadesia fusca was found on surfaces and in the littoral zone dominated by Blidingia (Bücking, in press). Food supply is of course only one of the many interacting factors influencing distribution limits and population dynamics. Carefoot (1977, pp. 46-47) remarked, that "The distribution of an organism represents the best compromise between its physiological and space requirements, and the conditions existing in the habitat". In particular the following must be taken into account: (1) alternating submersion and emersion; (2) high fluctuation of humidity, salinity and temperature - increasing with littoral height; (3) surface structure and composition - inclusive vegetation and sessile animals; $(4)$ mechanical stress due to wave action, brushing action of algae and sediment-mediated abrasion and (5) interspecific competition (cf. Lewis, 1964; Little \& Kitching, 1996). Nevertheless, in addition to the great risk of desiccation in the supralittoral zone, the abundance of low-quality food (lichens) would render impossible a build-up of a stable $H$. fusca population. Even the low nutritional quality of algae present in the middle and lower intertidal, e.g. Enteromorpha and red algae, may account for the low population density in this littoral region.

The low species diversity and abundance of mites of terrestrial origin in lower littoral zones are thought by many authors to be mainly the result of a restricted tolerance to submersion, a reduced time for foraging and - as previously mentioned - mechanical impact (Pugh \& King, 1985b; Schulte, 1977; Schuster, 1979). In view of the fact that (1) $H$. fusca is a common inhabitant of Baltic rock pools (Ganning, 1970, 1971; Östman \& Rönnberg, 1991) and that (2) specimens of the investigated intertidal population can live, feed and reproduce totally immersed for several months in the laboratory (Bücking, unpublished), foraging and inundation time can explain neither the absence of this species in the lower intertidal nor their low population density in the middle intertidal of the Weser estuary. The longer time of exposure to wave action and water currents in the lower intertidal zones might be an additional factor causing lower population densities. This view is supported by results of Östman \& Rönnberg (1991) who observed significantly lower abundances of $H$. fusca in rock pools subject to regular wave action caused by ships compared to undisturbed reference pools. According to Pugh \& King (1985b), the distribution of Hyadesiids on British rocky shores depends on the prevalence of barnacles which offer protection against wave action. However, both laboratory experiments on the ability of littoral mites to withstand mechanical stress and measurements of water pressure within the microhabitat of the mites, e.g. inside the dense algae cover or within cavities of the rock surface, have yet to be carried out.

Acknowledgements. The author thanks G. Davids for checking the translation and Prof. H. Witte for reading the manuscript.

\section{LITERATURE CITED}

Alberti, G., 1973. Emährungsbiologie und Spinnvermögen der Schnabelmilben (Bdellidae, Trombidiformes). - Z. Morph. Tiere 76, 285-338.

Bartsch, I. , 1978. Verbreitung der Halacaridae (Acari) im Gezeitenbereich der Bretagne Küste, eine ökologische Analyse. I. Verbreitung der Halacariden. - Cah. Biol. mar. 19, 363-383.

Bartsch, I., 1982. Halacaridae (Acari) von der Atlantikküste des borealen Nordamerikas. Ökologische und tiergeographische Faunenanalyse. - Helgoländer Meeresunters. 35, 13-46.

Bénard, F., 1961. Sur deux nouvelles espèces d'Acariens marins, Hyadesia tumida et Hyadesia furcillipes: sous-ordre des Sarcoptiformes, famille des Hyadesidae. - Cah. Biol. mar. 2, 71-96. 
Bliding, C., 1963. A critical survey of European taxa in Ulvales. I.: Capsosiphon, Percursaria, Blidingia, Enteromorpha. - Op. bot. Soc. bot. Lund 8, 1-160.

Bowman, C. E. \& Childs, M., 1982. Polysaccharidases in astigmatid mites (Arthropoda; Acari). Comp. Biochem. Physiol. 72B, 551-557.

Bücking, J., 1995. Untersuchungen zur Populations- und Emährungsbiologie von Hyadesia fusca (Lohmann, 1894) (Astigmata: Hyadesiidae), einer phytophagen Milbe des ästuarinen und marinen Felslitorals. Diss., Univ. Bremen, 172 pp.

Bücking, J., 1998. The population biology of a phytophagous mite of marine and estuarine rocky shores (Astigmata, Hyadesiidae). In: Evolution and ecology of Acari. Ed. by J. Bruin, L. P. S. van der Geest \& M. W. Sabelis. Kluwer, Dordrecht (in press).

Carefoot, T., 1970. A comparison of absorption and utilization of food energy in two species of tropical Aplysia. - J. exp. mar. Biol. Ecol. 5, 47-62.

Carefoot, T., 1973. Feeding, food preference, and the uptake of food energy by the supralittoral isopod Ligia pallasii. - Mar. Biol. 18, 228-236.

Carefoot, T., 1977. Pacific seashores: A guide to intertidal ecology. Univ. of Washington Press, Seattle, $208 \mathrm{pp}$.

Ernst, H., 1995. Raum-Zeit-Nutzung litoraler Milben terrestrischer Herkunft auf artifiziellen Hartsubstraten norddeutscher Ästuare. Diss., Univ. Bremen, 205 pp.

Ernst, H., 1996. The distribution and zonation of terrestrial mites inhabiting artificial rocky shores of estuaries in northern Germany. In: Acarology IX. Ed. by R. Mitchell, D. J. Horn, G. R. Needham $\&$ W. C. Welbourn. Ohio Biological Survey, Columbus, Ohio 1, 529-532.

Ernst, H., Siemer, F., Bücking, J. \& Witte, H., 1993. Die litorale Milbenzönose auf Uferbefestigungen des Weserästuars in Abhängigkeit von Substrat und Salzgehaltsgradient. - Inf. Natursch. Landschaftspfl. 6, 401-416.

Fain, A., 1981. Notes on the Hyadesiidae Halbert, 1915 and Algophagidae Fain, 1974, nov. tax. (Acari, Astigmata) with a redescription of Hyadesia currasaviensis Viets, 1936 and $H$. sellai Viets, 1937. - Acarologia 22, 47-61.

Fain, A. \& Schuster, R., 1984a. Four new species of the genus Amhyadesia Fain and Ganning, 1979 from the intertidal zone of several Indo-Pacific islands (Acari: Hyadesiidae). - Int. J. Acarol. 10, 103-111.

Fain, A. \& Schuster, R., 1984b. Two new species of mites of the family Hyadesiidae (Acari, Astigmata) from Costa-Rican and Brasilian Coasts. - Acarologia 25, 271-279.

Fain, A. \& Schuster, R., 1985. New observations on the Hyadesiidae (Acari, Astigmata). Description of three new species of the genus Hyadesia Megnin, 1891. - Acarologia 26, 67-77.

Fain, A. \& Schuster, R., 1989. Geographical distribution of the intertidal mite Hyadesia (Hyadesia) fusca (Lohmann, 1894) (Acari, Hyadesidae). - Bull. Annls Soc. r. ent. Belge 125, 293-295.

Ganning, B., 1970. Population dynamics and salinity tolerance of Hyadesia fusca (Lohmann) (Acarina, Sarcoptiformes) from brackish water rockpools, with notes on the microenvironment inside Enteromorpha tubes. - Oecologia 5, 127-137.

Ganning, B., 1971. Studies on chemical, physical and biological conditions in Swedish rockpool ecosystems. - Ophelia 9, 51-105.

Gerlach, D., 1984. Botanische Mikrotechnik. Thieme, Stuttgart, 311 pp.

Glombitzka, K.-K., 1970. Antimikrobielle Inhaltsstoffe in Algen. 2. Mitt.: Das Vorkommen von Acrylsäure in verschiedenen Meeresalgen. - Planta med. 18, 210-221.

Haase, R., 1995. Ökophysiologische Untersuchungen zur Dimethylsulfid-Emission der eulitoralen Grünalge Enteromorpha intestinalis (L.) Link. Diss., Univ. Bremen, 210 pp.

Halbert, J. N., 1920. The acarina of the seashore. - Proc. R. Ir. Acad. 35B, 106-155.

Keller, M. D., Bellows, W. K. \& Guillard, R. R. L., 1989. Dimethylsulfide production and marine phytoplankton: an additional impact of unusual blooms. - Coast. estuar. Stud. 35, 72-79.

Köhler, W., Schachtel, G. \& Voleske, P., 1992. Biostatistik. Springer, Berlin, 255 pp.

Kronberg, I., 1983. Ökologie der schwarzen Zone im marinen Felslitoral. Diss., Christian-AlbrechtsUniv., Kiel, 238 pp.

Leighton, D. L. \& Boolootian, R. A., 1963. Diet and growth in the black abalone, Haliotis cracherodii. - Ecology 44, 227-238.

Levinson, H. Z., Levinson, A. R. \& Offenberger, M., 1992. Effect of dietary antagonists and corre- 
sponding nutrients on growth and reproduction of the flour mite (Acarus siro L.). - Experientia $48,721-729$.

Lewis, J. R., 1964. The ecology of rocky shores. The English Univ. Press, London, 323 pp.

Little, C. \& Kitching, J.A., 1996. The biology of rocky shores. Oxford Univ. Press, Oxford, $240 \mathrm{pp}$.

Luxton, M., 1989. Mites of the family Hyadesiidae (Acari: Astigmata) from New Zealand. - Zool. J. Linn. Soc. 95, 71-95.

Östman, M. \& Rönnberg, O., 1991. Effects of ships' waves on rock-pools in the Åland archipelago, northern Baltic Sea. - Sarsia 76, 125-132.

Otto, G., 1936. Die Fauna der Enteromorphazone der Kieler Bucht. - Kieler Meeresforsch. 1, 1-48.

Paine, R. T. \& Vadas, R. L., 1969. Caloric values of benthic marine algae and their postulated relation to invertebrate food preference. - Mar. Biol. 4, 79-86.

Paul, V. J., 1992. Seaweed chemical defenses on coral reefs. In: Ecological roles of marine natural products. Ed. by V. J. Paul. Comstock Publ. Ass., London, 24-50.

Pugh. P. J. A. \& King, P. E., 1985a. Feeding in intertidal Acari. - J. exp. mar. Biol. Ecol. 94, 269-280.

Pugh. P. J. A. \& King, P. E., 1985b. The vertical distribution of the British intertidal Acari - The non halacarid fauna (Arachnida: Acari). - J. Zool., Lond. 207, 21-33.

Pugh, P. J. A. \& King, P. E., 1985c. Vertical distribution and substrate association of the British Halacaridae. - J. nat. Hist. 19, 961-968.

Reed, R. H., 1983. Measurement and osmotic significance of $\beta$-DMSP in marine macroalgae. - Mar. Biol. 4, 173-181.

Roussis, V., King, R. L. \& Fenical, W., 1993. Secondary metabolite chemistry of the Australian brown alga Encyothalia cliftonii : evidence for herbivore chemical defence. - Phytochemistry 34 , $107-111$

Schulte, G., 1976. Zur Nahrungsbiologie der terrestrischen und marinen Milbenfamilie Ameronothridae (Acari, Oribatei). - Pedobiologia 16, 332-352.

Schuite, G., 1977. Die Bindung der Landarthropoden an das Felslitoral der Meere und ihre Ursachen. Habilschr., Christian-Albrechts-Univ. Kiel., 223 pp.

Schuster, R., 1956. Der Anteil der Oribatiden an den Zersetzungsvorgängen im Boden. - Z. Morphol. Oekol. Tiere 45, 1-33.

Schuster, R., 1965. Die Ökologie der terrestrischen Kleinfauna des Meeresstrandes. - Verh. dt. zool. Ges. 1964, 492-521.

Schuster, R., 1979. Soil mites in the marine environment. In: Recent advances in acarology. Ed by J. G. Rodriguez. Acad. Press, New York 1, 593-602.

Schuster, R., 1988. Transoceanic distribution of air-breathing littoral mites. In: Progress in acarology. Ed. by G. P. Channabasavanna \& C. A. Viraktannath. Oxford \& IBH Publ., New Dehli 1, 355-362.

Siemer, F., 1996. The distribution, zonation, phenology and life cycle of the Halacaridae (Prostigmata) of artificial rocky shores located at the Weser estuary (Germany). In: Acarology IX. Ed. by R. Mitchell, D. J. Horn, G. R. Needham \& W. C. Welbourn. Ohio Biological Survey, Columbus, Ohio 1, 547-551.

Siemer, F. 1998. The influence of various kinds of food on the distribution and life cycle of Metarhombognathus armatus (Halacaridae: Rhombognathinae). In: Evolution and ecology of Acari. Ed. by J. Bruin, L. P. S. van der Geest \& M. W. Sabelis. Kluwer, Dordrecht (in press).

Travé, J., 1988. Contribution à la connaissance des acariens littoreaux de l'archipel de Kerquelen: quelques aspects des stratégies adaptives. - CNFRA (Com. Nat. Fr. Rech. Antarct.) 58, 111-127.

Winter, F. C. \& Estes, J. A., 1992. Experimental evidence for the effects of polyphenolic compounds from Dictyoneurum californicum Ruprecht (Phaeophyta, Laminariales) on feeding rate and growth in the red abalone Haliotus rufescens Swainson - J. exp. mar. Biol. Ecol. 155, 263-277.

Witte, H., 1972. Funktionsanatomische und ethologische Untersuchungen an der Milbenfamilie Erythraeidae. Diss., Christian-Albrechts-Univ. Kiel, $114 \mathrm{pp}$.

Young, A. J., Collins, J. C. \& Russel, G., 1987. Ecotypic variation in the osmotic responses of Enteromorpha intestinalis (L.) Link. - J. exp. Bot. 38, 1309-1324. 